\title{
Shade stress on maize seedlings biomass production and photosynthetic traits
}

\author{
Liuzheng Yuan ${ }^{1,2^{*}}$ (D) Jiayou Liu ${ }^{1,2}$ (D) Zhiyong Cai ${ }^{1,2}$ (D) Huiqiang Wang ${ }^{1,2}$ (D) Jiafeng Fu ${ }^{1,2}$ (D) \\ Hongtao Zhang, (D) Yundong Zhang, (D) Shidie Zhu ${ }^{1,2}$ (D) Weihua Wu ${ }^{1,2}$ (iD) Haixia Yan $^{1,2}$ (iD) \\ Hui Zhang ${ }^{1,2}$ (iD) Tianqi Li $^{1,2}$ (iD) Lu Zhang ${ }^{1,2}$ (D) Manman Yuan ${ }^{1,2}$ (D)
}

${ }^{1}$ Luohe Academy of Agricultural Sciences, 462300, Luohe Henan, China. E-mail: yuanliuzheng@126.com. *Corresponding author. ${ }^{2}$ Hazard Disaster Prevention and Reduction Engineering Technology Research Center of Henan, Henan, China.

\begin{abstract}
The responses of two maize (Zea mays L.) cultivars, 'LY336' (shade tolerant) and 'LC803' (shade sensitive), to shade stress in a pot experiment conducted in the 2015 and 2016 growing seasons were investigated. The impact of $50 \%$ shade stress treatment on shoot biomass, photosynthetic parameters, chlorophyll fluorescence, and malondialdehyde (MDA) content was evaluated. The shoot biomass of the two maize hybrids was decreased significantly by shade stress treatment, for shade stress $7 d$, the LC803 and LY336 were reduced by 56.7\% and $44.4 \%$ compared with natural light. Chlorophyll fluorescence parameters of LY336 were not significantly affected by shade stress, whereas those of LC803 were significantly affected, the $F_{o}$ increased under shade stress; however $F_{m} F_{V} / F_{M}$ and $\Phi P S I I$ were decreased under shade stress. Among photosynthetic parameters measured, net photosynthetic rate $\left(P_{n}\right)$, stomatal conductance $\left(G_{s}\right)$, and transpiration rate were significantly decreased compared with natural light, LY336 and LC803 reduction by $28.0 \%, 22.2 \%, 57.7 \%$ and $35.5 \%, 18.9 \%, 62.4 \%$; however, intercellular $\mathrm{CO}_{2}$ concentration (C) was significantly increased, for the two cultivars. Under shade stress for different durations (1, 3, 5, 7 d), $P_{n^{\prime}}, G_{s^{\prime}} C_{i^{\prime}}$ and MDA content differed significantly between the two cultivars. Results indicated that different maize genotypes showed different responses to shading. Shade-tolerant genotypes are only weakly affected by shade stress.
\end{abstract}

Key words: maizeshade stress, MDA, photosynthetic.

Efeitos do estresse de sombra na produção de biomassa de mudas de milho e características fotossintéticas

RESUMO: As respostas de duas cultivares de milho (Zea mays L.), 'LY336'(tolerante à sombra) e 'LC803' (sensível à sombra), ao estresse de sombra em um experimento em vaso conduzido nas safras de 2015 e 2016 foram investigadas. O impacto do tratamento de estresse de sombra de 50\% na biomassa da parte aérea, parâmetros fotossintéticos, fluorescência da clorofila e teor de malondialdeido (MDA) foi avaliado. A biomassa da parte aérea dos dois hibridos de milho foi reduzida significativamente pelo tratamento de estresse de sombra, para estresse de sombra 7 , o LC803 e LY336 foram reduzidos em 56,7\% e 44,4\% em comparação com a luz natural. Os parâmetros de fluorescência da clorofila de LY336 não foram significativamente afetados pelo estresse de sombra, enquanto aqueles de LC803 foram significativamente afetados, o Fo aumentou sob estresse de sombra, porém Fm, FV / FM e ФPSII diminuíram sob estresse de sombra. Entre os parâmetros fotossintéticos medidos, a taxa fotossintética líquida (Pn), a condutância estomática (Gs) e a taxa de transpiração diminuíram significativamente em comparação com a luz natural, redução de LY336 e LC803 em 28,0\%, 22,2\%, 57,7\% e 35,5\%, 18,9\%, 62,4\%, porém a concentração intercelular de CO2 (Ci) aumentou significativamente para as duas cultivares. Sob estresse de sombra para diferentes durações $(1,3,5,7 d)$, os teores de Pn, Gs, Ci e MDA diferiram significativamente entre as duas cultivares. Os resultados indicam que diferentes genótipos de milho apresentam diferentes respostas ao sombreamento. Os genótipos tolerantes à sombra são apenas fracamente afetados pelo estresse de sombra.

Palavras-chave: maize, shade stress, MDA, fotossintético.

\section{INTRODUCTION}

Maize (Zea mays L.) is the third most important crop worldwide after wheat and rice (WATTO et al., 2011). Domesticated maize is derived from a (sub) tropical progenitor, and has been imported and cultivated in many areas at higher latitudes around the world. In temperate regions, cultivated maize hybrids are subject to many abiotic stresses in the field, such as drought, high or low temperature, cloudy weather, and high rainfall. Among these abiotic stresses, cloudy weather from mid-June to mid-July in Huanghuaihai regions is the primary environmental factor that affects maize development, rain occurred frequently during the summer maize development season along with insufficient solar 
radiation(BAIZHAO REN, 2014) persistent shading is a restrictive meteorological factor that affects normal plant development and reduces grain yield, especially when accompanied by an increase in plant density in many areas of the world.

Previous reports have shown that shading stress is an important abiotic factor that affects many aspects of maize development and reproduction. Chen C Y et al. observed that vegetative growth and kernel number are greatly reduced relative to controls when grown under more extreme shading treatment during vegetative development (CHEN et al., 2014). Some researchers reported that the net photosynthetic rate (Pn) was significantly decreased after shading. The greatest reduction of Pn was from seedling to R6 treatment, followed shading from R1 to R6 and from V6 to R1treatment (BAIZHAO REN et al., 2016). In addition, when plants are shaded during grain filling, the kernel weight and yield are reduced; thus, kernel number and grain yield may be enhanced or decline in response to increased irradiation or shading of plants, respectively, during the reproductive period (CUI et al., 2014; WANG et al., 2020). Shading of maize at different developmental stages not only decreases grain yield, but also affects the normal development of other agronomically important traits, such as reduction in internode length (FOURNIER \& ANDRIEU, 2000), reduced Dry matter accumulation (GAO et al., 2017), delays in flowering and silking time (CUI et al., 2014; STRUIK, 1983; WANG et al., 2020), decrease in kernel set in the apical ear region or varying degrees of barrenness (CUI et al., 2014), inhibition of silk elongation (FOURNIER \& ANDRIEU, 2000; WANG et al., 2020), increase or decrease in plant height, delay in appearance of new leaves (STRUIK, 1983), and reduction in leaf thickness (WARD \& WOOLHOUSE, 2006). Yuan et al. identified a number of major quantitative trait loci (YUAN et al., 2012), protein regulatory networks(GAO et al., 2020) and microRNAs (YUAN et al., 2016) that regulate the mechanism of shade tolerance.

Maize as C4 plant, that is high photosyntheticrates, Light intensity had significant effects on photosynthetic rate, transpiration rate, stomatal conductance, light compensation point and light saturation point of leaves (BAIZHAO et al., 2016; BELLASIO \& GRIFFITHS, 2014; UBIEMA et al., 2012; WANG et al., 2017). The Chlorophyll fluorescence $(\mathrm{Fv} / \mathrm{Fm})$ has been used as a diagnostic tool to study the various environmental stresses, genotypic variation, altitudinal variation, and species-specific diurnal changes. Therefore, Fv/Fm is a sound method to diagnose seedling stock quality (AZAMAL et al., 2018; BAKER \& NEIL, 2008; GETNET et al., 2015; HUSEN, 2009, 2010; HUSEN et al., 2014; HUSEN et al., 2012; HUSSEIN et al., 2017). Therefore, it is important to investigate shade stress effects on the photosynthetic characteristics of summer maize. Because of the light requirement characteristics of summer maize, Shading level, shading time and exposure time of shade stress changed the influence of shade stress on maize. Different photosensitive maize had different responses to shade stress.to some extent, the difference of weak photosensitivity of maize was inversely proportional to the negative tolerance of maize: maize sensitivity to low light will reduce shade tolerance. Luoyu336 (LY336 shade tolerance, Figure 1) and Lianchuang 803 (LC803 shade sensitivity, Figure 2) were used to reveal shade stress reactions in photosynthesis and fluorescence characteristics under shading condition. investigate changes of photosynthesis, physiological, and biochemical characteristics further make clear photosynthetic mechanisms of shade sensitive and shade tolerant maize under shading condition. The objective of this study was to evaluate the effects of shading on different shading maize variety that selection of high-yielding, shade-tolerant maize is a basis for maize breeding to enhance the low-light tolerance of elite hybrids.

\section{MATERIALS AND METHODS}

\section{Study site}

The experiments were conducted at the experimental farm of the Luohe Academy of Agricultural Sciences, Luohe (34⒋ $\left.48^{\prime}, 113^{\circ} 42^{\prime} \mathrm{E}\right)$, which is located in northern China. The average annual temperature and average annual precipitation at the study site are $14.3{ }^{\circ} \mathrm{C}$ and $840.9 \mathrm{~mm}$, respectively. The soil in the experimental field is a yellow soil with contents of organic matter, total nitrogen, total phosphorus, and total potash of $12.7 \mathrm{~g} / \mathrm{kg}, 45.3 \mathrm{mg} /$ $\mathrm{kg}, 19.17 \mathrm{mg} / \mathrm{kg}$, and $140.87 \mathrm{mg} / \mathrm{kg}$, respectively.

\section{Experimental design, plant material, and management practices}

The maize hybrid 'Luoyu 336' (LY336; derived from the parents 'R2005' and 'Chang 7') shows strong tolerance of shading stress. LY336 is a popular cultivar with growers in the study area and the growth period is about $98 \mathrm{~d}$. The hybrid 'Lianchuang 803' (LC803; bred from the parents 'CT1669' and 'CT3354') is sensitive to shading stress and has a growth period of about $102 \mathrm{~d}$. 


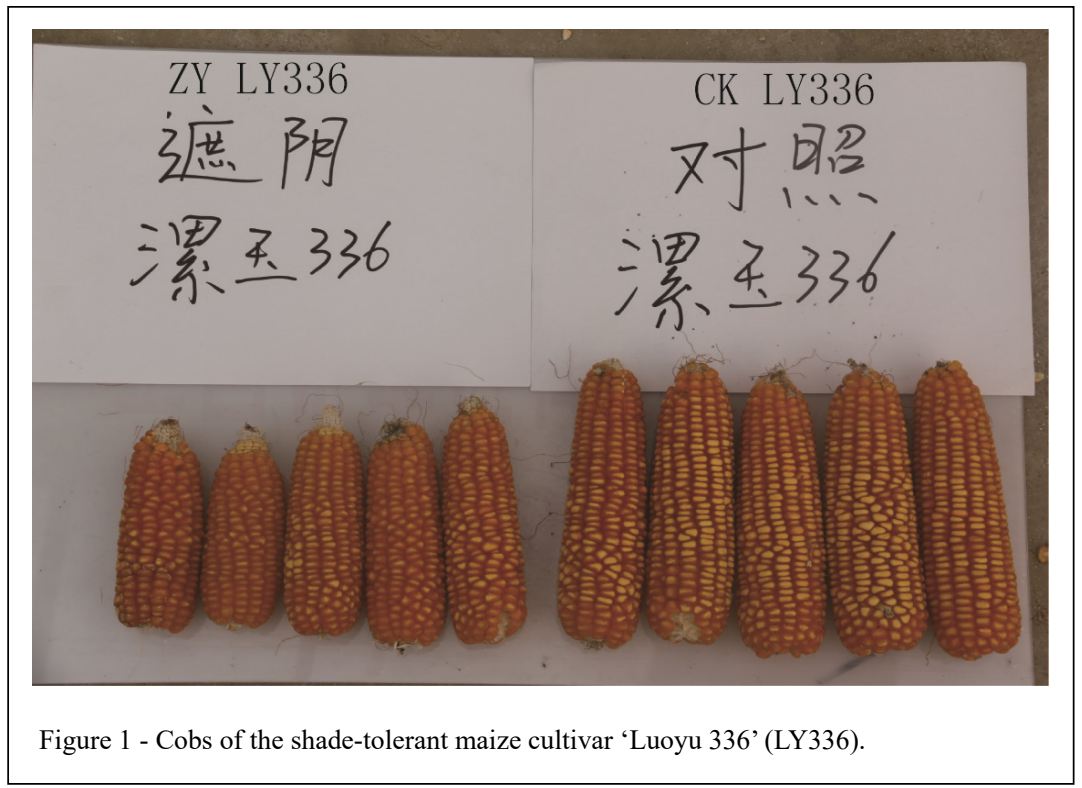

In the present experiment, natural light (the control; CK) and 50\% shade treatment were applied. The $50 \%$ shade treatment was conducted from the seedling stage to the six-leaf stage and aimed to artificially simulate low light intensity. A movable scaffold $3 \mathrm{~m}$ high, $40 \mathrm{~m}$ long, and $8 \mathrm{~m}$ wide was covered with black polypropylene fabric to provide $50 \%$ reduction in incident light, and was placed in an East-West orientation. Only the upper side of the frame and the east- and west-facing sides to $2 \mathrm{~m}$ above the frame base were covered with shade fabric. The upper side of the frame was $2-2.5 \mathrm{~m}$ above the top of the crop canopy to create a microclimate within the frame otherwise

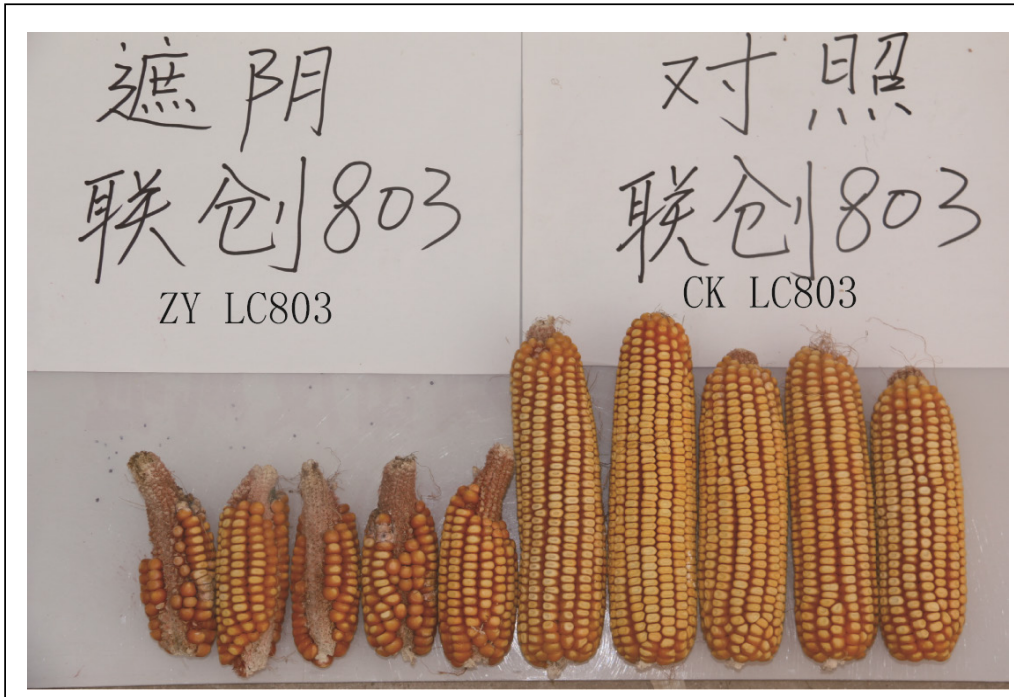

Figure 2 - Cobs of the shade-sensitive maize cultivar 'Lianchuang 803' (LC803). 
comparable to the ambient environment of the field (Table 1). Data for atmospheric $\mathrm{CO}_{2}$ concentration, light intensity, relative humidity, and air temperature within the frame were recorded daily at 11:00 using a LI-6400 Portable Photosynthesis System (LI-COR, Inc., Lincoln, NE, USA). For each treatment, plants were cultivated in 20 plastic pails (height $20 \mathrm{~cm}$, inner diameter $23 \mathrm{~cm}$ ). Each pail contained $12.5 \mathrm{~kg}$ topsoil (0-20 cm depth) that was first sieved and blended. Seedlings of LY336 and LC803 were planted on 3 June 2015 and 10 June 2016. Before sowing, $12 \mathrm{~g}$ compound fertilizer $\left(25 \% \mathrm{~N}, 18 \% \mathrm{P}_{2} \mathrm{O}_{5}\right.$, and $12 \%$ $\mathrm{K}_{2} \mathrm{O}$ ) was incorporated in the soil of each pail and the soil was irrigated. After germination, a sufficient supply of water was provided throughout the growing season, preventing disease.

Measurement of biomass, photosynthetic parameters, and lipid peroxidation

Shoot biomass

When the maize plants attained the six-leaf stage, three representative plants were harvested by excising the shoot. The harvested plants were oven dried at $105{ }^{\circ} \mathrm{C}$ for $30 \mathrm{~min}$, and thereafter at $85{ }^{\circ} \mathrm{C}$ until constant weight was attained.

\section{Chlorophyll fluorescence}

Chlorophyll fluorescence parameters were recorded in parallel to gas exchange measurements on the same leaf (the sixth leaf) using a modulated fluorescence monitoring system (FMS-II, Hansatech, King's Lynn, UK) when the sixth leaf was unfurled. The leaves were dark-adapted for $30 \mathrm{~min}$ before measurements were recorded. After $5 \mathrm{~s}$, the light intensity was set at $75 \%$ of the maximum irradiance $(>3000 \mu \mathrm{mol} / \mathrm{m} / \mathrm{s})$. Minimum $\left(F_{\mathrm{o}}\right)$, maximum $\left(F_{\mathrm{m}}\right)$, and variable $\left(F_{\mathrm{v}}=F_{\mathrm{m}}-F_{\mathrm{o}}\right)$ fluorescence in the dark- modified condition, $F_{\mathrm{v}} / F_{\mathrm{o}}$ ratio, and maximum quantum efficiency of photosystem II $\left(F_{\mathrm{v}} / F_{\mathrm{m}}\right)$ were recorded. The $F_{\mathrm{v}} / F_{\mathrm{o}}$ ratio is used as an index of the potential photosynthetic capacity of photosystem II (PSII; Roháček 2002).

\section{Photosynthetic parameters}

Net photosynthetic rate $\left(P_{\mathrm{n}}\right)$, transpiration rate $\left(T_{\mathrm{r}}\right)$, stomatal conductance $\left(G_{\mathrm{s}}\right)$, and intercellular $\mathrm{CO}_{2}$ concentration $\left(C_{\mathrm{j}}\right)$ were determined using a LI6400 portable open-flow gas exchange system (LICOR) from 9:00 to 12:00. The photosynthetically active radiation was $1000 \pm 12 \mu \mathrm{mol} / \mathrm{m}^{2} / \mathrm{s}, \mathrm{CO}_{2}$ concentration was $350 \pm 2 \mathrm{~cm}^{3} / \mathrm{m}^{3}$, leaf temperature was $28.0 \pm 0.8^{\circ} \mathrm{C}$, and atmospheric flow rate was $0.5 \mathrm{dm}^{3} / \mathrm{min}$.

\section{Malondialdehyde content}

The malondialdehyde (MDA) content was measured using the thiobarbituric acid reaction as described by HEATH \& PACKER (1968). A fresh leaf sample $(0.5 \mathrm{~g})$ was homogenized in $10 \mathrm{~mL}$ of $5 \%$ trichloroacetic acid. The homogenate was centrifuged at $15,000 \times \mathrm{g}$ for $10 \mathrm{~min}$. To a $2 \mathrm{~mL}$ aliquot of the supernatant, $4 \mathrm{~mL}$ of $0.5 \%$ thiobarbituric acid in $20 \%$ trichloroacetic acid was added. The mixture was heated at $95{ }^{\circ} \mathrm{C}$ for $30 \mathrm{~min}$, then quickly cooled in an ice bath and centrifuged at $10,000 \times g$ for $10 \mathrm{~min}$. The absorbance of the supernatant was recorded at 532 and $600 \mathrm{~nm}$. After subtracting the non-specific absorbance at $600 \mathrm{~nm}$, the MDA content was calculated using its molar extinction coefficient $(155 \mathrm{mM} / \mathrm{cm})$ and the results expressed as nanomoles (MDA) per gram fresh weight.

\section{Statistical analysis}

As the experimental results were consistent in 2015 and 2016, the averages for the 2 years were calculated. Three replicate measurements

Table 1 - Effects of shading treatment on the microclimate under the shade frame in the experimental field.

\begin{tabular}{lccccc}
\hline year & Treatment & $\mathrm{CO}_{2}$ concentration & Light intensity & Relative humidity & Air temperature \\
\hline & & $\left(\mu \mathrm{mol} \cdot \mathrm{mol}^{-1}\right)$ & $\left(\mu \mathrm{mol} \cdot \mathrm{m}^{-2} \cdot \mathrm{s}^{-1}\right)$ & $(\%)$ & $\left({ }^{\circ} \mathrm{C}\right)$ \\
2015 & Low light & $368.52 \pm 2.33 \mathrm{a}$ & $765.36 \pm 15.36 \mathrm{~b}$ & $73.56 \pm 0.21 \mathrm{a}$ & $32.2 \pm 0.16 \mathrm{a}$ \\
& Control & $362.42 \pm 2.05 \mathrm{a}$ & $1326 \pm 20.13 \mathrm{a}$ & $68.86 \pm 0.32 \mathrm{a}$ & $33.6 \pm 0.22 \mathrm{a}$ \\
\multirow{2}{*}{2016} & Low light & $372.21 \pm 2.56 \mathrm{a}$ & $752.17 \pm 20.26 \mathrm{~b}$ & $75.37 \pm 0.23 \mathrm{a}$ & $30.5 \pm 0.32 \mathrm{a}$ \\
& Control & $369.28 \pm 1.65 \mathrm{a}$ & $1315 \pm 12.28 \mathrm{a}$ & $70.36 \pm 0.35 \mathrm{a}$ & $32.1 \pm 0.18 \mathrm{a}$ \\
\hline
\end{tabular}

Note: Values are means \pm SD. Values followed by a different letter within a column are significantly different $(\mathrm{P}<0.05)$. 
were recorded for all data and subjected to analysis of variance using Microsoft EXCEL and SPSS statistical software.

\section{RESULTS}

\section{Shoot biomass}

Dry matter accumulation has a major impact on maize yield. Under natural light, the shoot biomass of LC803 was higher than that of LY336. Shading stress significantly influenced shoot biomass at the seeding stage (Figure 3). Under shading, the shoot biomass of the two cultivars was severely diminished compared with that under natural light, but the percentage reduction differed between the cultivars. Under shading for $7 \mathrm{~d}$, the shoot biomass of LC 803 was reduced by $56.7 \%$ and that of LY336 was reduced by $44.4 \%$ compared with the biomass produced under natural light.

\section{Chlorophyll fluorescence}

Analysis of chlorophyll $a$ fluorescence parameters revealed that the $F_{\text {o }}$ of LY336 increased non-significantly by $3.9 \%$ in the shading treatment, whereas the $F_{\mathrm{o}}$ of LC803 increased significantly by $32.1 \%$ in the shading treatment $(P<0.05)$, compared with that under natural light (Table 2). The $F_{\mathrm{m}}$ of LC803 decreased significantly $(P<0.05)$ compared with that of the natural-light control, but a significant effect was not observed in LY336. Under natural light, the two cultivars exhibited a mean $F_{\mathrm{v}} / F_{\mathrm{M}}$ ratio of approximately 0.81-0.83; under shading stress $F_{\mathrm{v}} /$ $F_{\mathrm{M}}$ decreased but only significantly in LC803. The $\Phi P S I I$ decreased in both cultivars in response to shade treatment; this response was significant in LC803, for which $\Phi$ PSII decreased by $23.3 \%(P<0.05)$.

\section{MDA content}

Malondialdehyde is the final product of lipid peroxidation and is often used as an index of lipid peroxidation, thus MDA content can reflect the stress tolerance of a plant. The smaller the increase in MDA content, the less the oxidative damage to cell membranes. The MDAcontent in the leaves of the two cultivars differed significantly between the shading treatment and control (Figure 4). The MDA contents in the shading treatments were increased compared with those of the natural-light control. The leaf MDA contents of LC803 were higher than those of LY336 under low light intensity. In LC803 the MDA content grown up under increased duration of low-light stress, whereas that LY336 remained similar to that observed under natural light.

\section{Photosynthetic parameters}

Analysis of photosynthetic parameters revealed that $P_{\mathrm{n}}, T_{\mathrm{r}}$, and $G_{\mathrm{s}}$ were significantly

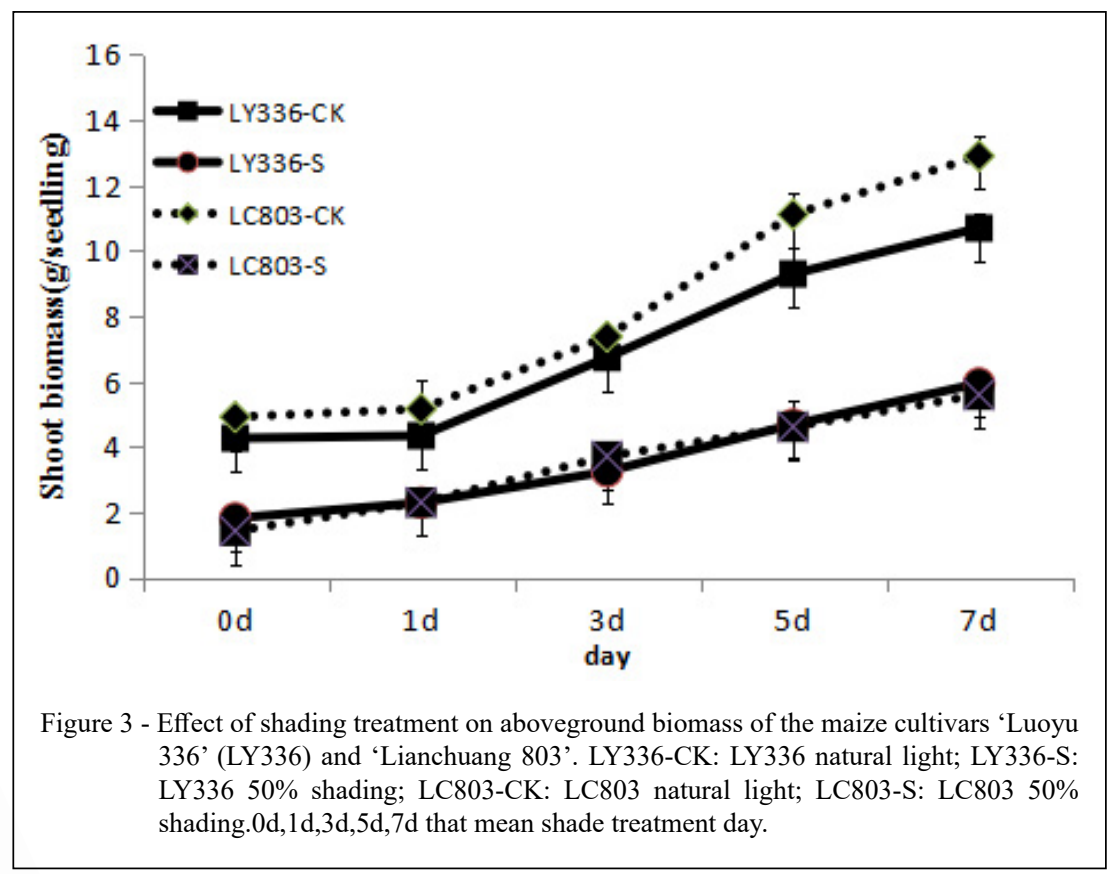

Ciência Rural, v.52, n.3, 2022. 
Table 2 - Effects of shading treatment on chlorophyll fluorescence parameters of the maize cultivars 'Luoyu 336' (LY336) and 'Lianchuang 803' (LC803) under low light stress.

\begin{tabular}{ccccccc}
\hline Variety & Treatment & Fo & $F m$ & $F v$ & $F v / F m$ \\
\hline \multirow{2}{*}{ LY336 } & light & $101.30 \pm 1.06 \mathrm{a}$ & $616.15 \pm 32.16 \mathrm{a}$ & $498.57 \pm 26.15 \mathrm{a}$ & $0.81 \pm 0.01 \mathrm{a}$ & $0.68 \pm 0.03 \mathrm{a}$ \\
& shading & $105.28 \pm 1.96 \mathrm{a}$ & $609.06 \pm 28.37 \mathrm{a}$ & $489.12 \pm 30.6 \mathrm{a}$ & $0.80 \pm 0.01 \mathrm{a}$ & $0.63 \pm 0.02 \mathrm{a}$ \\
\multirow{2}{*}{ LC803 } & light & $113.35 \pm 2.65 \mathrm{~b}$ & $676.25 \pm 22.06 \mathrm{a}$ & $561.20 \pm 28.16 \mathrm{a}$ & $0.83 \pm 0.01 \mathrm{a}$ & $0.73 \pm 0.04 \mathrm{a}$ \\
& shading & $149.71 \pm 6.31 \mathrm{a}$ & $635.69 \pm 18.28 \mathrm{a}$ & $481.81 \pm 32.12 \mathrm{~b}$ & $0.76 \pm 0.01 \mathrm{~b}$ & $0.56 \pm 0.02 \mathrm{~b}$ \\
\hline
\end{tabular}

Note: Values are means $\pm \mathrm{SD}$. the values a significant between the control and shading treatment for each cultivar and each variable $(\mathrm{P}<0.05)$.

decreased $(\mathrm{P}<0.05)$ (Figure 5). The respective parameters for LY336 were decreased by $28.0 \%$, $22.2 \%$, and $57.7 \%$, and those of LC803 were decreased by $35.5 \%, 18.9 \%$, and $62.4 \%$, respectively, compared with those under natural light. The $C_{\mathrm{i}}$ of LY336 and LC803 increased significantly $(\mathrm{P}<0.05)$ compared with that under natural light. The $C_{\mathrm{i}}$ of LC803 increased more substantially (by $28.7 \%$ ) than that of LY336 under shade. Furthermore, the $C_{\mathrm{i}}$ of
LY336 was lower than that of LC803 under natural light, perhaps because the $\mathrm{CO}_{2}$ assimilation ability of mesophyll cells of LC803 was reduced.

\section{DISCUSSION}

For summer maize in Huanghuaihai region in China, shade stress is an important environmental stress factor that affects maize development. Artificial

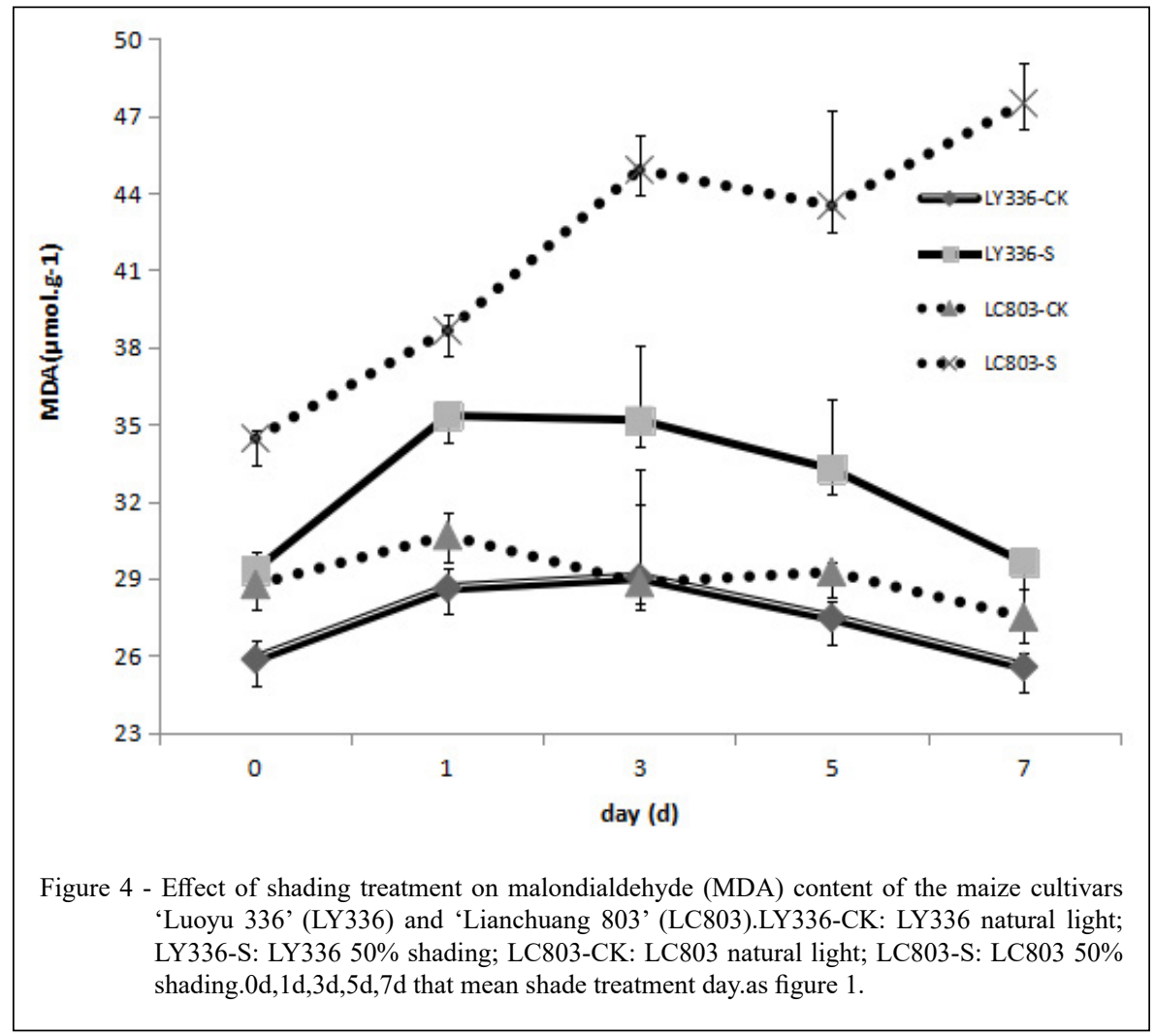

Ciência Rural, v.52, n.3, 2022. 


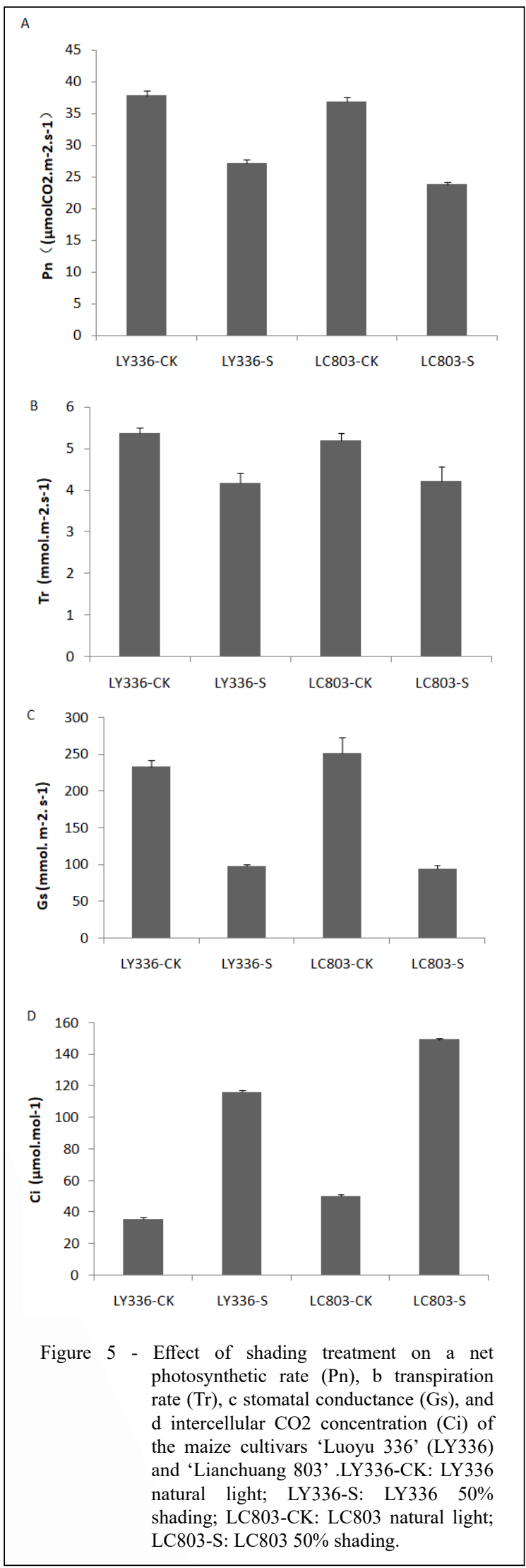

shading may have effects similar to those of high plant density. Hashemi-Dezfouli and Herbert reported that the rate of apparent photosynthesis in ear leaves was reduced significantly by both increase in plant density and shading (HASHEMI-DEZFOULI \& HERBERT, 1992). In our study, the shoot biomass of different cultivars was observed under shading conditions. Shading significantly reduced both maize shoot biomass, especially LC803 (Figure 3). Results are consistent with previous studies (DILLA et al., 2017; VILLALOBOS et al., 1992), This study showed that the decrease of shoot biomass under shade stress was mainly caused by photosynthetic rate limitation.

Under heat stress, the production and accumulation of membrane lipid, for example MDA destroy cell structure and function, bringing about changes in cell membrane fluidity and permeability(XU et al., 2006), the experimental results showed that MDA content of the two maize variety increased significantly under shade stress, This was consistent with the report that heat stress increased MDA content in various organs of wheat seedlings (SAVICKA M, 2010); however, the value in LC803 was significantly higher than that in LY336. Result showed that LC803 is more severely affected by shade stress at the cellular level, that might be one of the reasons that physiological difference showed in shade stress between LC803 and LY336. This study demonstrated that LY336 could maintain low MDA content after shade stress treatment indicating that the shade tolerant variety LY336 has stronger ability to reduce free radical damage to cell than LC803.

Physiological processes are extremely sensitive to shading treatment, as illustrated by photosynthesis activity under the shading treatment in the present experiment. The photosynthetic rate of the two cultivars (LY336 and LC803) was highly responsive to shading. Net photosynthetic rate $\left(P_{\mathrm{n}}\right)$ is the most important characterized photosynthetic parameter, the size of $P_{n}$ is an important indicator of the photosynthetic capacity of maize. Shading was the main reason that led to the decline of net photosynthetic $\operatorname{rate}\left(P_{\mathrm{n}}\right)$, while the difference of $P_{\mathrm{n}}$ under shading was determined by the photosensitivity of the maize varieties, previous study showed that the genetic factor to be the main reason for shading sensitivity in maize lines(YUN et al., 2014).in our study reported that the net photosynthetic rate of LC803(shading sensitive) was lower than LY336, the reason for the decreasing of the $P_{\mathrm{n}}$ under shading was the stomatal limitation transferring into a nonstomatal limitation and the intercellular carbon 
dioxide concentration increased. The research results are consistent with the predecessors (BAIZHAO et al., 2016; WANG et al., 2017).

The chlorophyll fluorescence parameters are commonly used to evaluate the photosynthetic efficiency of crops under adverse circumstances (HAMANI et al., 2020), many studies have reported that changes of chlorophyll fluorescence parameters are an important pointer (ZARCO-TEJADA et al., 2013). The changes of chlorophyll fluorescence parameters are closely related to photosynthesis, which further reveals the adaptability of Paeonia under shading stress (WAN et al., 2020), the maximum photochemical conversion efficiency $\left(\mathrm{F}_{\mathrm{v}} /\right.$ $\mathrm{F}_{\mathrm{m}}$ ) decreased significantly in response to shading condition, especially LC803 decreased significantly than LY336, being the changing trend of DPSII was similar. The above indicated that the light energy captured by the PSII antenna pigment is mainly used for photosynthesis under shading condition, and in order to the damage of under shading condition on the photosynthetic system, for ensure normal photosynthesis. Under the shading treatment, $P_{n}$, $F_{\mathrm{V}} / F_{\mathrm{M}}$, and ФPSII decreased significantly, which showed that PSII capacity was damaged. The decline in $F_{\mathrm{v}} / F_{\mathrm{m}}$ was considered to be predominantly due to reduction in PSII efficiency. Both LY336 and LC803 showed a decrease in $F_{\mathrm{v}} / F_{\mathrm{m}}$ under exposure to shade stress compared with that of the natural-light control, but the effect of shading was stronger in LC803. Although, $P_{\mathrm{n}}, G_{\mathrm{s}}$, and $T_{\mathrm{r}}$ of LY336 and LC803 were decreased, the $C_{\mathrm{i}}$ of LY336 and LC803 increased in response to shading treatment. Different maize genotypes showed different responses to shading. Shade-tolerant genotypes are only weakly affected by shade stress. Previous studies have shown that there are differences in photosynthetic rate and the chlorophyll fluorescence parameters under shade stress. Our experiment reached a similar conclusion. The main reason for the decrease of net photosynthetic rate $(\mathrm{Pn})$ is the decrease of light intensity, in addition to the difference of adaptability to shading condition determined by the photosynthetic capacity of maize varieties, for example the shading physiological regulation mechanism of the shading tolerant maize (LY336) was better than that of the shading sensitive maize (LC803).

In conclusion, under shading condition, the photosynthesis and chlorophyll fluorescence characters of LY336 were superior to LC803.The shade resistant mechanism was associated with highly photosynthetic rate mechanism.

\section{ACKNOWLEDGEMENTS}

This research was Supported by China Agriculture Research System of MOF and MARA (nycytx-02-70).

We thank Robert McKenzie, PhD, from Liwen Bianji, Edanz Group China (www.liwenbianji.cn/ac), for editing the English text of a draft of this manuscript.

\section{DECLARATION OF CONFLICT OF INTEREST}

The authors declare no conflict of interest. The founding sponsors had no role in the design of the study; in the collection, analyses, or interpretation of data; in the writing of the manuscript, and in the decision to publish the results.

\section{AUTHORS' CONTRIBUTIONS}

Liuzheng Yuan, Jiayou Liu and Yundong Zhang conceived and designed the experiments; Liuzheng Yuan, Huiqiang Wang, Jia-feng Fu, Hongtao Zhang, WU Weihua Wu, Haixia Yan, and Hui Zhang performed the experiments; Liuzheng Yuan and Tianqi Li analyzed the data; Liuzheng Yuan and Huiqiang Wang wrote the paper. All authors critically revised the manuscript and approved of the final version.

\section{REFERENCES}

AZAMAL,H., et al. Salicylic acid alleviates salinity-caused damage to foliar functions, plant growth and antioxidant system in Ethiopian mustard (Brassica carinata A. Br.). Agriculture and Food Security, v.7, p.44, 2018. Available from: $<$ https://doi.org /10.1186/s.40066-018-0194-0>. Accessed: Jul. 05, 2018. doi: 10.1186/s.40066-018-0194-0.

BAIZHAO R. et al. Effects of waterlogging on the yield and growth of summer maize under field conditions. Canadian Journal of Plant Science, v.94, p.23-31, 2014.vailable from: $<$ https://doi.org/10.4141/cjps2013-175>. Accessed: Oct. 02, 2013. doi: $10.4141 / \operatorname{cjps} 2013-175$.

BAIZHAO, R.et al. Effects of shading on the photosynthetic characteristics and mesophyll cell ultrastructure of summer maize: The Science of Nature, v.103, p.67. 2016. Available from: $<$ https:// doi:10.1007/s00114-016-1392-x>. Accessed: Jul. 20, 2013. doi: 10.1007/s00114-016-1392-x.

BAKER, N. R. Chlorophyll fluorescence: a probe of photosynthesis in vivo. Annu Rev Plant Biol, v.59, p.89, 2008. Available from: <https://doi:10.1146/annurev. arplant.59.032607.092759>. Accessed: Jul. 10, 2008. doi: 10.1146/ annurev.arplant.59.032607.092759.

BELLASIO, C., and H. GRIFFITHS. Acclimation of $\mathrm{C} 4$ metabolism to low light in mature maize leaves could limit energetic losses during progressive shading in a crop canopy. Journal of Experimental Botany, v.65, p.3725, 2014. Available from: <https://doi:10.1093/jxb/eru052>. Accessed: Mar. 03, 2014. doi: $10.1093 / \mathrm{jxb} / \mathrm{eru} 052$

CHEN, C. Y., et al. Effects of Shading on Grain-Filling Properties and Yield of Maize at Different Growth Stages. Acta Agronomica Sinica, v.40, p.1650, 2014. Available from: <https://10.3724/ 
SP.J.1006.2014.01650>. Accessed: Mar. 03, 2014. doi: 10.3724/ SP.J.1006.2014.01650.4

CUI, H., et al. Effects of shading on spike differentiation and grain yield formation of summer maize in the field. International Journal of Biometeorology, v.59, p.1189-1200, 2014. Available from: $\quad<$ https://doi:10.1007/s00484-014-0930-5>. Accessed: Nov.08, 2014. doi: 10.1007/s00484-014-0930-5.

DILLA, A., et al. Potential of the APSIM model to simulate impacts of shading on maize productivity: Agroforestry Systems, v.92, p.16991709,2017. Available from: <https://doi:10.1007/s10457-017-01190>. Accessed: Sept. 04, 2017. doi: 10.1007/s10457-017-0119-0.

FOURNIER, C., and B. ANDRIEU, Dynamics of the Elongation of Internodes in Maize ( Zea mays L.). Effects of Shade Treatment on Elongation Patterns. Annals of Botany, v.86, p.1127-1134, 2000 Available from: $<$ https://doi:10.1006/anbo.2000.1280>. Accessed: Oct. 24, 2000. doi: 10.1006/anbo.2000.1280.

GAO, J., et al. Grain yield and root characteristics of summer maize (Zea mays L.) under shade stress conditions. Journal of Agronomy and Crop Science. 203(6), 562-573,2 017. Available from: <https://doi:10.1111/jac.12210>. Accessed: Mar. 09, 2017. doi: $10.1111 /$ jac. 12210 .

GAO, J., et al. Physiological and comparative proteomic analysis provides new insights into the effects of shade stress in maize (Zea mays L.). BMC Plant Biology, v. 20, 2020. Available from: $<$ https://doi.org/10.1186/s12870-020-2264-2>. Accessed: Feb. 05, 2020.doi: 10.1186/s12870-020-2264-2.

GETNET, Z., et al. Growth water status physiological biochemical and yield response of stay green sorghum (Sorghum bicolor (L.) Moench) varieties-A field trial under drought-prone area in amhara regional state Ethiopia: Journal of Agronomy, 14(4), 2015. Available from: <https://doi.10.3923/ja.2015.188.202>. Accessed: Apr. 2015. doi: 10.3923/ja.2015.188.202.

HAMANI, M., et al. Reduction in Photosynthesis of Cotton Seedling under Water and Salinity Stresses is Induced by both Stomatal and Non stomatal Limitations. Journal of Irrigation and Drainage Engineering. 2020. Available from: <https:// doi.10.13522/j.cnki.ggps.2020173>. Accessed: Nov. 2020. doi: 10.13522/j.cnki.ggps.2020173.

HASHEMI-DEZFOULI, A., et al. Intensifying Plant Density Response of Corn with Artificial Shade. Agronomy Journal, v.84, p.547-551, 1992. Available from: < https://doi.10.2134/agronj1992 $.00021962008400040001 \mathrm{x}>$. Accessed: Jul. 1992. doi: 10.2134/ag ronj1992.00021962008400040001x.

HUSEN, A., Growth, chlorophyll fluorescence and biochemical markers in clonal ramets of shisham (Dalbergia sissoo Roxb.) at nursery stage. New Forests, v.38, p.117-129, 2009. Available from: <https://doi.10.1007/s11056-009-9141-z>. Accessed: Apr. 02, 2009.doi: 10.1007/s11056-009-9141-z.

HUSEN, A., Growth characteristics, physiological and metabolic responses of teak (Tectona grandis Linn. f.) clones differing in rejuvenation capacity subjected to drought stress. Silvae Genetica v.59, p.124-136,2010. vailable from: < https://doi.10.1515/sg2010-0015>. Accessed: Apr. 10, 2010. doi: 10.1515/sg-2010-0015.

HUSEN, A., et al. Growth, water status and leaf characteristics of Brassica carinata under drought and rehydration conditions.
Brazilian Journal of Botany, v.37, p.217-227,2014. Available from: <https://doi.10.1007/s40415-014-0066-1>. Accessed: Jun. 28, 2014. doi: 10.1007/s40415-014-0066-1.

HUSEN, A., et al. Biodiversity Status in Ethiopia and Challenges, Environmental Pollution and Biodiversity, 2012. Available from: <https://ISBN:978-93-5056-149-2>. Accessed: Jun. 28, 2012. ISBN:978-93-5056-149-2.

HUSSEIN, M., et al. Salinity-induced modulation of plant growth and photosynthetic parameters in faba bean (Vicia faba) cultivars. Pakistan Journal of Botany, v.49, p.867-877, 2017. Available from: $\quad<$ https://www.researchgate.net/publication/317682051>. Accessed: Jun. 282017.

SAVICKAM, Š. N., Effects of high temperature on malondialdehyde content, superoxide production and growth changes in wheat seedlings (Triticum aestivum L.). Ekologija. 56(1), 26-33, 2010. Available from: <https://doi:10.2478/v10055-010-0004-x>. Accessed: Mar. 18, 2010. doi: 10.2478/v10055-010-0004-x.

STRUIK, P. C., Effects of short and long shading during differnet stages of growth on develpment, productivity and quality of forage maize (Zea mays L). Netherlands Journal of Agricultural Science, v.31, p.101-124,1983.vailable from: <https:// doi:10.1016/0304-3924(83)90008-4>. Accessed: Mar. 18, 1983. doi: 10.1016/0304-3924(83)90008-4.

UBIERNA, N., et al. The efficiency of C4 photosynthesis under low light conditions in Zea mays, Miscanthus $x$ giganteus and Flaveria bidentis. Plant Cell \& Environment, v.36, 365-381, 2012. Available from: <https://doi:10.1111 /j.1365-3040.2012.02579.x>. Accessed: Jul. 06, 2012. doi: 10.1111/j.1365-3040.2012.02579.x.

VILLALOBOS, F. J.,et al. Effects of shading on dry matter partitioning and yield of field-grown sunflower. European Journal of Agronomy, v.1, p.109-115, 1992. Available from: $<$ https://doi:10.1016/s1161-0301(14)80008-7>. Accessed: Mar. 18, 1992. doi: 10.1016/s1161-0301(14)80008-7.

WAN, Y,et al. Shade effects on growth, photosynthesis and chlorophyll fluorescence parameters of three Paeonia species. PeerJ, v.8, p.e9316, 2020. Available from: <https://doi:10.7717/ peerj.9316>. Accessed: Jun. 18, 2020. doi: 10.7717/peerj.9316.

WANG, S. Post-Silking Shading Stress Affects Leaf Nitrogen Metabolism of Spring Maize in Southern China. Plants, v.9, p.210, 2020. Available from: <https://doi:10.3390/plants9020210>. Accessed: Feb. 06, 2020.doi: 10.3390/plants9020210.

WANG, J.et al. Photosynthesis and chlorophyll fluorescence reaction to different shade stresses of weak light sensitive maize. Pakistan Journal of Botany, v.49, p.1681-1688,2017.

WARD, D. A.et al. Comparative effects of light during growth on the photosynthetic properties of NADP-ME type C4 grasses from open and shaded habitats. I. Gas exchange, leaf anatomy and ultrastructure*. Plant Cell \& Environment, v.9, p.261-270, 2006. Available from: <https://doi:10.1111/1365-3040.ep11611679>. Accessed: Apr. 06, 2006. doi: 10.1111/1365-3040.ep11611679.

WATTOO, M. H. et al. Aerosol-Assisted Chemical Vapor Deposition of Thin Films of Cadmium Sulfide and Zinc Sulfide Prepared from Bis (dibutyldithiocarbamato) Metal Complexes. Arabian Journal for Science \& Engineering, v.36, p.565-571, 
2011. Available from: <https://doi:10.1007/s13369-011-0060-x>. Accessed: Jun. 21, 2011. doi: 10.1007/s13369-011-0060-x.

$\mathrm{Xu}, \mathrm{S}$., et al. Effects of heat acclimation pretreatment on changes of membrane lipid peroxidation, antioxidant metabolites, and ultrastructure of chloroplasts in two cool-season turfgrass species under heat stress. Environmental \& Experimental Botany, v.56, p.274-285, 2006. Available from: <https://doi:10.1016/j. envexpbot.2005.03.002 >. Accessed: Jun. 21, 2006. doi: 10.1016/j. envexpbot.2005.03.002.

YUAN, L.et al. Differential miRNA expression in maize ear subjected to shading tolerance. Acta Physiologiae Plantarum v.38, p.80, 2016. Available from: <https://doi:10.1007/s11738-0162094-x>. Accessed: Feb. 26, 2016. doi: 10.1007/s11738-016-2094-x.
YUAN, L.et al. QTL Analysis of Shading Sensitive Related Traits in Maize under Two Shading Treatments: Plos One, v.7, p.e38696, 2012. Available from: <https://doi:10.1371/journal.pone.0038696>. Accessed: Jun. 19, 2012. doi: 10.1371/journal.pone.0038696.

YUN, Z. et al. Effects of shade on photosynthetic characteristics and chlorophyll fluorescence of Ardisia violacea. Chinese Journal of Applied Ecology. v.25, p.1940-1948, 2014. Available from: <http:// www.cjae.net/CN/Y2014/V25/I7/1940>. Accessed: Jul. 18, 2014.

ZARCO-TEJADA, PJ, et al. Relationships between net photosynthesis and steady-state chlorophyll fluorescence retrieved from airborne hyperspectral imagery. REMOTE SENS ENVIRON, v.2013, 136, p.247-258, 2013. Available from: $<$ https://doi:10.1016/j.rse.2013.05.011>. Accessed: May, 01, 2013. doi: 10.1016/j.rse.2013.05.011. 